\title{
A new species of Stempellina Thienemann \& Bause from Mato Grosso do Sul, Brazil (Diptera, Chironomidae)
}

\author{
Lívia Maria Fusari \& Carlos José Einicker Lamas
}

Universidade de São Paulo, Museu de Zoologia - MZUSP, Laboratório de Diptera, São Paulo, SP, Brazil. liviafusari@gmail.com; einicker@usp.br

\begin{abstract}
A new species of Stempellina Thienemann \& Bause from Mato Grosso do Sul, Brazil (Diptera, Chironomidae). The male imago of Stempellina sofiae sp. nov. is described and illustrated based on material collected in Mato Grosso do Sul, Brazil, during the expeditions of the project SISBIOTA Brazil. One of the core focuses of this project is identifying and describing new species of Diptera from central Brazil. The new species herein presented can be easily segregated by their congeneric by the rounded shape of the superior volsella.
\end{abstract}

KEYWORDS. Biodiversity; Insecta; Neotropical region; Tanytarsini; taxonomy.

The Tanytarsini genus Stempellina was erected by Thienemann \& Bause in Bause (1913), with Tanytarsus (Calopsectra) bausei Kieffer, 1911 as the type-species. This is a relatively small, but worldwide distributed genus. There are 22 spe-cific names described in Stempellina in the world and 14 in the Holarctic region (Gilka 2005). Still according to Gilka (2005) only 8 species of this genus known in the Holarctic are recognized as valid and five species are recognized for the Palaearctic region. In the Neotropical region only two species are known, $S$. cururui Säwedal, 1984 and $S$. tarumai Säwedal, 1984 from the Amazon region (Spies \& Reiss 1996).

During years, the taxonomic status of Stempellina underwent a number of changes, from the level of a group of species within a subgenus of that name (Edwards, 1929) to separate subgenus (e.g. Tokunaga, 1938; 1939) to genus (Brundin 1947). Originally, Stempellina comprised species that are at present classified within other genera, e.g., Stempellinella Brundin, 1947 and Neozavrelia Goetghebuer, 1941. This has so far been an impediment in formulating an unambiguous generic diagnosis.

According of Gilka (2005), in a revision of the European species, the combination of characters which distinguish adult males of Stempellina from other genera of the tribe Tanytarsini are the presence of a 12-segmented antennal flagel-lum, presence of at least one spur on mid and hind tibiae, small cylindrical superior volsella and lack of digitus. However, the Brazilian species do not have a cylindrical superior volsella but have an ornamentation on the anal point (splits into 2 or 3 branches), thus characterizing the cururuigroup (Säwedal 1984). The new species, Stempellina sofiae sp. nov., cannot be inserted in this group due the absence of this ornamentation on the anal point, which suggests a closer relationship with the European species. We believe that with increased collections in different biomes in Brazil, as well as throughout the Neotropical region, and descriptions of new species it will be possible to clarify the current gaps in the knowledge of the genus.

In this paper, a new species of Stempellina, based on males, is described and illustrated. The specimens were collected as part of the program SISBIOTA Brazil, which has enabled the collecting and description of chironomids from surveys in central Brazil (Wiedenbrug et al. 2012).

\section{MATERIAL AND METHODS}

Both male specimens were sorted from a Malaise trap sample which had been set on a farm in Serra da Bodoquena, Mato Grosso do Sul State, Brazil, and are deposited in the Museu de Zoologia da Universidade de São Paulo, São Paulo, Brazil (MZUSP).

Specimens were placed in a coverslip, and mounted into a flat slide using Euparal ${ }^{\circledR}$ following the procedures outlined by Sæther (1969). The terminology follows Sæther (1980). Measurements were made according to the method suggested by Sæther (1968) and Schlee (1966). The measurements are given with the range observed between the two studied specimens.

\section{TAXONOMY}

\section{Stempellina sofiae sp. nov.} (Figs. 1-2)

Diagnosis. Stempellina sofiae sp. nov. differs from other congeneric species by the stem of median volsella long, armed with a bunch of simple setae and long lamellae and the rounded volsella superior.

Description. Male $(\mathrm{n}=1-2)$

Total length $0.88-0.90 \mathrm{~mm}$. Wing length $0.73-0.76 \mathrm{~mm}$, width $0.19-0.20 \mathrm{~mm}$. Total length/wing length ratio 1.2 . Wing 

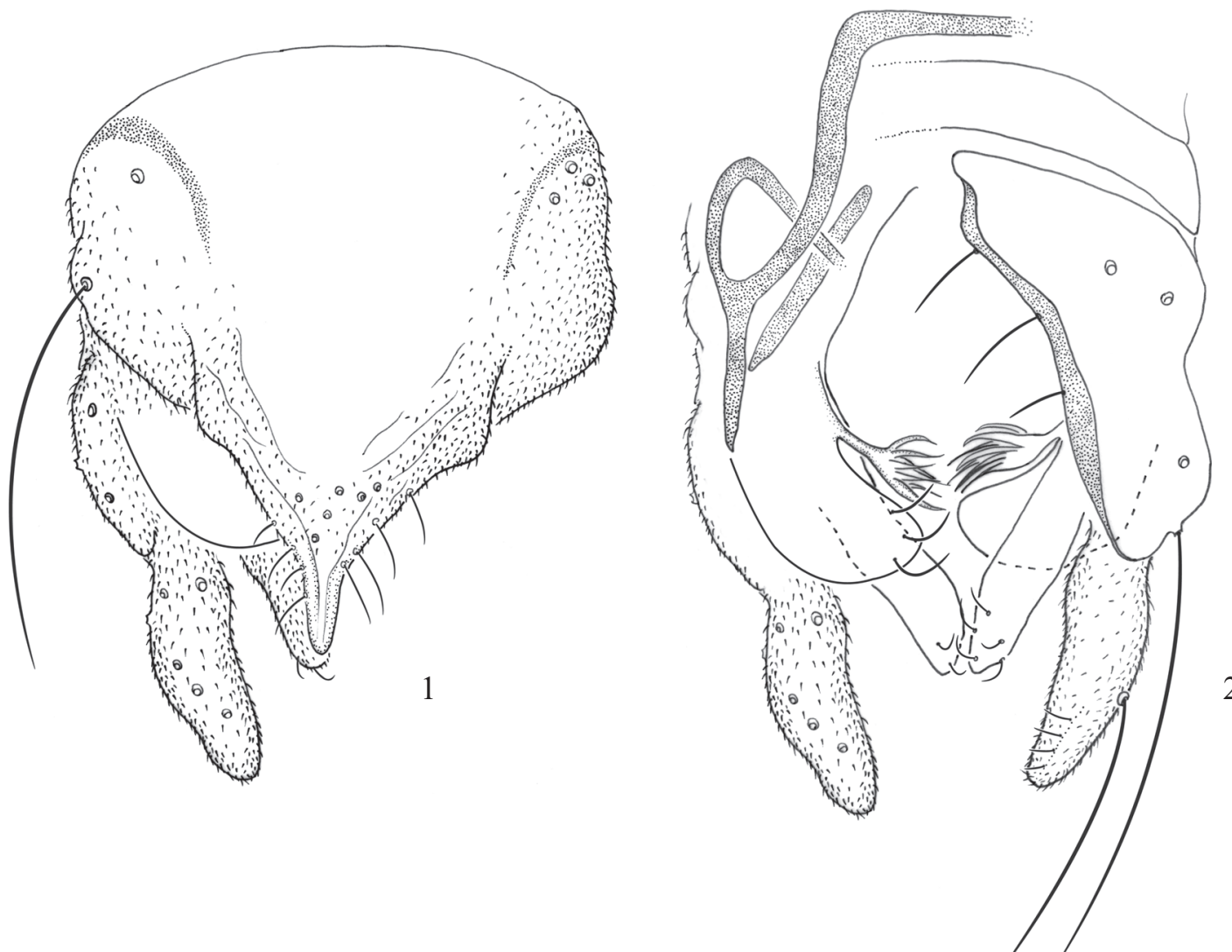

Figs. 1-2. Stempellina sofiae sp. nov., male. 1. Hypopygium, dorsal view. 2. Hypopygium with tergite IX and anal point removed; dorsal view to the left, ventral view to the right.

length/profemur length ratio 2.4-2.5. Color (in slide): Thorax with brown mesosternum and scutal stripes. Thorax, abdomen and legs light brown.

Head. Frontal tubercles small. Antenna lost. Clypeus with 7 setae. Lengths of palpomeres $1-5$ (in $\mu \mathrm{m}$ ): 18; 18-21; 44$48 ; 50-58 ; 76$.

Thorax. With scutal tubercle. Ac 3; Dc 6; Scts 6. Wing. Squama bare. Anal lobe reduced, cell $\mathrm{m}_{3+4}$, distal part of cells $\mathrm{m}_{1+2}$ and $\mathrm{r}_{4+5}$ with macrotrichia. Cells $\mathrm{r}_{4+5}$ and $\mathrm{m}_{1+2}$ with a single row of macro-trichia in distal three-quarters. Legs. Length (in $\mu \mathrm{m}$ ) of femur and tibia as in Table I.

Table I. Length (in $\mu \mathrm{m}$ ) of femur (Fe) and tibia (Ti) of Stempellina sofiae sp. nov., male $(\mathrm{n}=2)$.

\begin{tabular}{ccc}
\hline & $\mathrm{Fe}$ & $\mathrm{Ti}$ \\
\hline $\mathrm{L}_{1}$ & $308-309$ & $164-171$ \\
$\mathrm{~L}_{2}$ & $361-368$ & $263-268$ \\
$\mathrm{~L}_{3}$ & $381-392$ & $286-294$ \\
\hline
\end{tabular}

Hypopygium. Anal point 18-20 $\mu \mathrm{m}$ long, on tapering part with laterally positioned setae pointing in lateral direction, anal crests absent. Phallapodeme 27-28 $\mu \mathrm{m}$ long, transverse sternapodeme 31-36 $\mu \mathrm{m}$. Superior volsella rounded, about 22-27 $\mu \mathrm{m}$ long and with 3 setae in anteromedian position. Digitus absent. Stem of median volsella long $(17-20 \mu \mathrm{m})$ curved and directed caudally, bearing simple setae, lamellae placed latero-apically. Inferior volsella $35-37 \mu \mathrm{m}$ long, with 5 apical setae. Gonocoxite 52-58 $\mu \mathrm{m}$ long. Gonostylus $31-$ $35 \mu \mathrm{m}$ long. HR 1.48-1.87. HV 2.52-2.90.

Female and immatures. Unknown.

Etymology. In honor of Dr. Sofia Wiedenbrug for her contribution to knowledge of Chironomidae.

Distribution. Only known from the type locality. The specimens of Stempellina sofiae sp. nov. were collected in a malaise trap installed on the borders of a small stream with alternate stony bottom and coarse sand of an area covered with semideciduous forest.

Type material: Holotype, 1 male, BRAZIL, Mato Grosso do Sul, Serra da Bodoquena, Fazenda Califórnia, 2041'50"S 5652'54"W, Malaise trap, 22.viii.2011-06.ix.2011, Lamas, C. J. E. leg. (MZUSP). Paratype: 1 male, same data as holotype (MZUSP).

\section{ACKNOWLEDGMENTS}

The authors would like to thank the owners of Fazenda Califórnia (Bodoquena, Mato Grosso do Sul, Brazil) the welcome and hospitality they have given to us and all staff of dipterists of our project. To Conselho Nacional de Desenvolvimento Científico e Tecnológico (CNPq) (grant 563256/ 2010-9) and Fundação de Amparo a Pesquisa do Estado de São Paulo (FAPESP) (grant 2010/52314-0) for the financial 
support given to the project "Rede temática para estudos de diversidade, sistemática e limites distribucionais de Diptera nos estados do Mato Grosso, Mato Grosso do Sul e Rondônia". L. M. Fusari is currently supported by CNPq through the SISBIOTA Program (grants 150078/2012-9; 150434/2013-8). C. J. E. Lamas is CNPq research fellow.

\section{REFERENCES}

Brundin, L. 1947. Zur Kenntnis der Swedischen Chironomiden. Arkiv för Zoologi 39: 1-95.

Bause, E. 1913. Die Metamorphose der Gattung Tanytartus und einiger verwandter Tendipedidenarten. Archiv für Hydrobiologie 2: 1-126.

Gilka, W. 2005. A systematic review of European Stempellina Thienemann et Bause, 1913 (Diptera: Chironomidae) with description of a new species from Fennoscandia. Annales Zoologici 55: 413-419.

Schlee, D. 1966. Präparation und Ermittlung von Meßwerten an Chironomidae (Diptera). Gewässer und Abwässer 41/42: 169-193.

Sæther, O.A. 1968. Chironomids of the Finse Area, Norway, with special reference to their distribution in a glacier brook. Archiv für
Hydrobiologie 64: 426-483.

Sæther, O.A. 1969. Some Nearctic Podonominae, Diamesinae, and Orthocladiinae (Diptera: Chironomidae). Bulletin/Fisheries Research Board of Canada 170: 1-154.

Sæther, O.A. 1980. Glossary of chironomid morphology terminology (Diptera: Chironomidae). Entomologica Scandinavica (Supplement) 14: $1-51$.

Säwedal, L. 1984. The cururui-group of the genus Stempellina Thienemann \& Bause. Amazonian Tanytarsini II. (Diptera: Chironomidae). Entomologica Scandinavica (Supplement) 15: 141-149.

Spies, M. \& Reiss, F. 1996. Catalog and bibliography of Neotropical and Mexican Chironomidae (Insecta, Diptera). Spixiana (Supplement) 22: $61-119$.

Tokunaga, M. 1938. Chironomidae from Japan (Diptera) X. New or littleknown midges with description of the metamorphosis of several species. The Philippine Journal of Science 65: 313-383.

Tokunaga, M. 1939. Chironomidae from Japan (Diptera) XI. New or littleknown midges with description of the metamorphosis of tor-rential species. The Philippine Journal of Science 69: 297-345.

Wiedenbrug, S., Lamas, C.E. \& Trivinho-Strixino, S. 2012. A review of the genus Corynoneura Winnertz (Diptera: Chironomidae) from the Neotropical region. Zootaxa 3574: 1-61. 